\title{
Risk assessment for West Nile Virus in Northern Greece (2010-2013)
}

\author{
S Gewehr ${ }^{*}$, S Kalaitzopoulou, L Slavi, S Mourelatos \\ From The 1st Conference on Neglected Vectors and Vector-Borne Diseases (EurNegVec): with Management \\ Committee and Working Group Meetings of the COST Action TD1303 \\ Cluj-Napoca, Romania. 8-11 April 2014
}

Since the large WN fever epidemic in Central Macedonia in 2010 caused by WNV Lineage 2, with a total of 262 cases (197 neuroinvasive, incidence rate 1:140), WNV cases are reported every year from different areas throughout Greece (2011: 100 cases/75 neuroinvasive, 2012: 161/ 109, 2013: 86/51). WN fever has become one of the most important issues for the National Health Authorities in terms of vector-borne diseases.

From 2011 and onwards, for the surveillance of WNV in Central Macedonia, two major networks were established by Ecodevelopment in collaboration with the Hellenic $\mathrm{CDC}$, the region of Central Macedonia and four specialized laboratories: 1) A network of $60 \mathrm{CO}_{2}$-traps for adult mosquitoes at fixed sites monitored biweekly for 4 months every year. Pools of 10-50 Culex spp. are forwarded weekly to the laboratories for the detection of WNV. 2) A network of sentinels (domestic pigeons and/or backyard chickens, 40 -50 hencoops or pigeon coops, 400-450 samples/year) for blood sampling in early summer and/or at the end of the hot season.

In the plain of Thessaloniki, in early summer (June) the seroconversion in chickens reached $11,9 \%$ (28 positive/236 chickens) in 2011 versus $4,1 \%$ (8 positive/197 chickens) in 2013. The corresponding average weekly Minimum Infection Rate (M.I.R.) for the period mid June-end August was 1.73 in 2011 and 0.39 in 2013 respectively. These data seem to support the hypothesis that it is possible to relate the level of WNV circulation (infected mosquitoes and animal sentinels) with the upcoming human WNV cases: 16 human neuroinvasive cases were recorded in 2011 versus 5 cases in 2013.

The follow up of the epidemiological risk through these two networks in combination with the weekly epidemiological reports of the Hellenic CDC and the results of larval

* Correspondence: gewehr@ecodev.gr

Ecodevelopment S.A., Thessaloniki, Greece and take full advantage of:

- Convenient online submission

- Thorough peer review

- No space constraints or color figure charges

- Immediate publication on acceptance

- Inclusion in PubMed, CAS, Scopus and Google Scholar

- Research which is freely available for redistribution 